\title{
Profile and scientific production of Brazilian National Council of Technological and Scientific Development researchers in Pediatrics
}

\author{
Perfil e produção científica dos pesquisadores do Conselho Nacional de Desenvolvimento Científico e \\ Tecnológico na área de Pediatria
}

\author{
Perfil y producción científica de los investigadores del Consejo Nacional de Desarrollo Científico y \\ Tecnológico en el área de Pediatría
}

\begin{abstract}
Maria Christina L. Oliveira ${ }^{1}$, Daniella Reis B. Martelli², Sergio Veloso Pinheiro ${ }^{3}$, Debora Marques Miranda4, Isabel Gomes Quirino ${ }^{5}$, Barbara Gusmão L. Leite ${ }^{2}$, Enrico Antonio Colosimo ${ }^{6}$, Ana Cristina S. e Silva ${ }^{7}$, Hercílio Martelli-Júnior ${ }^{8}$, Eduardo Araujo Oliveira ${ }^{9}$
\end{abstract}

\section{ABSTRACT}

Objective: To evaluate the profile and the scientific production of researchers in Pediatrics with scholarship from the National Counsel of Technological and Scientific Development.

Methods: The Lattes curricula of 34 researchers in Pediatrics with active scholarships, from 2006 to 2008 were included in the analysis. The variables of interest were: gender, affiliation, time since PHD, tutoring of undergraduate students, mentorship of masters and doctors, scientific production and the papers' impact.

Results: In a total of 411 researchers in Medicine, 34 (8\%) belonged to Pediatrics. Males (77\%) and scholars in the category 2 of productivity (62\%) prevailed. Three states of Brazil were responsible for approximately $90 \%$ of the researchers: São Paulo (53\%), Minas Gerais (21\%), and Rio Grande do Sul (15\%). During their academic career, the Pediatrics researchers have pub- lished 3,122 articles with a median of 89 articles per researcher (interquartile range $-\mathrm{IQ}=51-119$ ). Of the total, 40 and $59 \%$ articles were indexed in the Web of Science and Scopus databases, respectively. The Pediatrics researchers have published papers in 599 journals with a median impact factor of $2.35(\mathrm{IQ}=1.37-3.73)$ for the 323 indexed journals.

Conclusions: The Pediatrics researchers have a relevant scientific output from the quantity point of the view, but there is a need to improve quality.

Key-words: scientific publication indicators; Pediatrics; Medicine; education, Medical, Graduate; Health Sciences.

\section{RESUMO}

Objetivo: Avaliar o perfil e a produção científica de pesquisadores de Pediatria, cadastrados como
Instituição: Universidade Federal de Minas Gerais (UFMG), Belo Horizonte, MG, Brasil

'Doutora em Gastroenterologia pela UFMG; Professora-Associada do Departamento de Pediatria da UFMG, Belo Horizonte, MG, Brasil

${ }^{2}$ Mestre em Ciências da Saúde pelo Programa de Pós-Graduação em Ciências da Saúde da Universidade Estadual de Montes Claros (Unimontes), Montes Claros, MG, Brasil

${ }^{3}$ Doutor em Ciências Biológicas pelo Instituto de Ciências Biológicas da UFMG; Professor-Adjunto do Departamento de Pediatria da UFMG, Belo Horizonte, MG, Brasil

${ }^{4}$ Doutora em Farmacologia Bioquímica e Molecular pela UFMG; Professora Adjunto do Departamento de Pediatria da UFMG, Belo Horizonte, MG, Brasil ${ }^{5}$ Doutora em Ciências da Saúde pela UFMG, Belo Horizonte, MG, Brasil ${ }^{6}$ Doutor em Estatística pela University of Wisconsin; Professor-Titular do Departamento de Estatística da UFMG, Belo Horizonte, MG, Brasil

'Doutora em Ciências da Saúde pela UFMG; Professora-Titular do Departamento de Pediatria da UFMG, Belo Horizonte, MG, Brasil

${ }^{8}$ Doutor em Ciências da Saúde pelo Programa de Pós-Graduação em Ciências da Saúde da Unimontes; Professor-Titular do Programa de PósGraduação em Ciências da Saúde da Unimontes, Montes Claros, MG, Brasil 9Doutor em Ciências da Saúde pela UFMG; Professor-Titular do Departamento de Pediatria da UFMG, Belo Horizonte, MG, Brasil
Endereço para correspondência:

Eduardo Araujo Oliveira

Rua Engenheiro Amaro Lanari, 389

CEP 30310-580 - Belo Horizonte/MG

E-mail: eduolive812@gmail.com

Fonte financiadora: Fundação de Amparo à Pesquisa do Estado de Minas Gerais (Fapemig) - PPM-00345-11 e 00286-11

Conflito de interesse: nada a declarar

Recebido em: 27/11/2012

Aprovado em: 29/4/2013 
bolsistas de produtividade científica do Conselho Nacional de Desenvolvimento Científico e Tecnológico.

Métodos: O currículo Lattes de 34 pesquisadores em Pediatria, com bolsas ativas no triênio 2006 a 2008, foram incluídos na análise. As variáveis de interesse foram: sexo, instituição, tempo de doutoramento, orientação de alunos de graduação, mestres e doutores, artigos publicados e impacto da publicação.

Resultados: De um total de 411 pesquisadores em Medicina, 34 (8\%) foram identificados como da área de Pediatria. Houve uma predominância do gênero masculino (77\%) e de bolsistas na categoria 2 (62\%). Três estados foram responsáveis por aproximadamente $90 \%$ dos pesquisadores: São Paulo (53\%), Minas Gerais (21\%) e Rio Grande do Sul (15\%). No total da carreira acadêmica, os pesquisadores em Pediatria publicaram 3.122 artigos, sendo a mediana de 89 artigos por pesquisador (intervalo interquartil - IQ=51-119). Desse total, 40 e 58,5\% foram artigos indexados nas bases de dados Web of Science e Scopus, respectivamente. Os pesquisadores em Pediatria publicaram em 599 periódicos, com mediana de fator de impacto de 2,35 $(\mathrm{IQ}=1,37-3,73)$ para os 323 periódicos indexados.

Conclusões: Na presente investigação, observou-se que os pesquisadores na área de Pediatria apresentam uma produção científica relevante do ponto de vista quantitativo, mas há necessidade de aprimoramento qualitativo das publicações.

Palavras-chave: indicadores de produção científica; Pediatria; Medicina; educação de Pós-Graduação em Medicina; Ciências da Saúde.

\section{RESUMEN}

Objetivo: Evaluar el perfil y la producción científica de los investigadores en Pediatría catastrados como becarios de productividad científica del Consejo Nacional de Desarrollo Científico y Tecnológico.

Métodos: Se incluyó en el análisis el currículo Lattes de 34 investigadores en Pediatría con becas activas en el trienio 2006 a 2008. Las variables de interés fueron: sexo, institución, tiempo de doctoramiento, orientación de alumnos de la carrera, maestros y doctores, artículos publicados e impacto de la publicación.

Resultados: De un total de 411 investigadores en Medicina, 34 (8\%) fueron identificados como del área de Pediatría. Hubo una predominancia del género masculino $(77 \%)$ y de becarios en la categoría 2 (62\%). Tres provincias fueron responsables por un 90\% de los investigadores: São Paulo (53\%), Minas Gerais (21\%) y Rio Grande do Sul (15\%). En el total de la carrera académica, los investigadores en Pediatría publicaron 3.122 artículos, siendo la mediana de 89 artículos por investigador (intervalo intercuartil - IQ=51-119). De ese total, 40 y 58,5\% fueron artículos indexados en las bases de datos Web of Science y Scopus, respectivamente. Los investigadores en Pediatría publicaron en 599 periódicos, con mediana de factor de impacto de 2,35 (IQ=1,37-3,73) para los 323 periódicos indexados.

Conclusiones: En la presente investigación, se observó que los investigadores en el área de Pediatría presentan una producción científica relevante desde la mirada cuantitativa, pero hay necesidad de perfeccionamiento cualitativo de las publicaciones.

Palabras clave: indicadores de producción científica; Pediatría; Medicina; educación de Postgrado en Medicina; Ciencias de la Salud.

\section{Introduction}

Brazil is one of the few middle-income countries that have a consistent state program for funding the production of scientific knowledge, despite the limited budget allocated to research in relation to gross domestic product ${ }^{(1-3)}$. On the other hand, in recent years there has been a significant increase in scientific production and training of researchers ${ }^{(4)}$. Scientific publications of Brazilian researches in indexed journals jumped from 14,237 , in 2003, to 30,415 , in 2008, according to data from Thomson Reuters ${ }^{(5)}$. Several factors have contributed to the current positive cycle of Brazilian scientific production, as the increase in the federal budget for science and technology, which rose, in 2008, from 1.26 to $1.43 \%$ of Brazil's gross domestic product ${ }^{(6)}$. Furthermore, the increase in scientific research is associated with various stimulating mechanisms established by various development agencies in the country ${ }^{(7,8)}$.

In this context, stands out a particular form of funding created by the National Council for Scientific and Technological Development (Conselho Nacional de Desenvolvimento Cientifico e Tecnológico - CNPq) in the 1970s, called scientific productivity fellowship (PQ). This fellowship was designed as a form of support to researchers with outstanding scientific output ${ }^{(9)}$. Several studies have examined the academic production of researchers supported by $\mathrm{CNPq}$, in different areas of knowledge ${ }^{(9-13)}$. A recent study assessed the profile of $\mathrm{CNPq}$ researchers in Medicine, in which several areas of specialty were compared ${ }^{(12,14)}$. However, systematic analyzes of researchers in the field of Pediatrics are still scarce.

Therefore, the present cross-sectional study aimed to describe the demographic characteristics and the scientific productivity of $\mathrm{CNPq}$ research fellows in Medicine whose area of specialty is Pediatrics. 


\section{Method}

This was a cross-sectional study, consisting initially of a database with 411 researches registered at CNPq as PQ fellows, according to a list provided by this federal agency for research funding in February $2009^{(14)}$. It was considered as area of expertise the one specifically appointed by the researcher in his Lattes. When this information was omitted, the scientific production of the researcher in the last 5 years was analyzed and the area with a predominance of published and/or advised topics was adopted. In specific cases of well-defined subareas, for instance, Pediatric Nephrology, the researcher was included in the area of Pediatrics, and the subarea was considered in a separate variable (in this case, Nephrology). Thus, following this methodology, the Lattes curricula of 34 researchers in Pediatrics with active fellowships in the triennium 2006-2008 were included in the analysis.

After the identification of the fellow researchers, the Lattes curricula, publicly available on the Lattes platform $(\mathrm{CNPq})$, were systematically consulted. From the resumes, a database was created, with information related to the distribution of $\mathrm{PQ}$ researchers by category $(1 \mathrm{~A}, 1 \mathrm{~B}, 1 \mathrm{C}, 1 \mathrm{D} \text {, and category } 2)^{(15)}$, geographical and institutional distribution, completion time of doctoral degree, scientific production (scientific articles), and training in human resources (undergraduate, master's, and doctoral supervisions). To investigate scientific production, all publications and supervisions during the researcher's career were considered. Supervisions and publications in the last 5 years were also analyzed, considering the period of 2004-2008.

The following variables were analyzed: sex, researcher's institution, Doctorate's completion time, doctoral institution, fellowship category, supervisions of undergraduate research fellows (bolsistas de iniciação científica-BIC), master's and $\mathrm{PhD}$ students, and publications in journals. Regarding supervisions and publications, the absolute values of the entire scientific career and the values for the period 2004-2008 were evaluated. Moreover, the supervisions and publications adjusted according to doctorate's completion time were computed. The Thomson Reuters Web of Science (Institute for Scientific Information - http://apps. JCRknowledge.com/) - and Scopus (http://www.scopus.com/ home.url) databases were also investigated. Both were searched through electronic websites from Capes (Coordination for the Improvement of Higher Education Personnel - http://novo. periodicos.capes.gov.br/). In these databases, it was searched for scientific articles published by researchers listed in CNPq's database. The scientific name of the researcher used in this investigation was that provided in Lattes, but there was an intense search for possible variations of researchers' names. Performance indicators were also included in the analysis, such as the number of citations, $b$-index, and $m$-index ${ }^{(16-20)}$.

The development of the database and statistical analyses were performed with the Statistical Package for the Social Sciences (SPSS), version 18.0, for Windows. For statistical analysis, in relation to researcher categories, category 1 researchers (levels $1 \mathrm{~A}$, $1 \mathrm{~B}, 1 \mathrm{C}$ and $1 \mathrm{D})$ were grouped, since there was only one scholar acting in the field of Pediatrics in categories $1 \mathrm{~A}$ and 1B. Thus, all comparisons between researcher categories were between levels 1 and 2. Continuous data were reported using median and interquartile range (IQ). The nonparametric Mann-Whitney test was used for comparison between researcher categories. Nominal or dichotomous variables were compared using the chi-square test. The level of significance was set at $5 \%$.

\section{Results}

Among the total of 411 researchers in Medicine, 34 (8.0\%) were identified as working in the area of Pediatrics. The distribution of the 34 researchers by gender and fellowship category is summarized in Table 1 . There was a predominance of male patients $(76.5 \%)$ and grants in category $2(61.8 \%)$. There was no significant difference in the distribution of categories between genders $(p=0.48)$. Three Brazilian states were responsible for approximately $90 \%$ of researchers: São Paulo $(\mathrm{n}=18 ; 53.0 \%)$, Minas Gerais $(n=7 ; 21.0 \%)$ and Rio Grande do Sul $(n=5 ; 15.0 \%)$. In relation to home institution, researchers were spread over nine different institutions in the country. However, four institutions were responsible for approximately $82 \%$ of researchers: Universidade de São Paulo (USP) ( $\mathrm{n}=12 ; 35.0 \%$ ), Universidade Federal de Minas Gerais (UFMG) ( $\mathrm{n}=7 ; 21,0 \%)$, Universidade Federal de São Paulo (UNIFESP) ( $\mathrm{n}=5 ; 15.0 \%)$, and Pontifícia Universidade Católica do Rio Grande do Sul (PUC-RS) ( $\mathrm{n}=4 ; 12.0 \%)$. Six researchers $(17.6 \%)$ reported acting in the area of Pneumology

Table 1 - Distribution of research fellows in Pediatrics according to gender and CNPq classification $(n=34)$

\begin{tabular}{lccc}
\hline $\begin{array}{l}\text { Fellowship } \\
\text { category }\end{array}$ & $\begin{array}{c}\text { Male } \\
\mathbf{n}(\%)\end{array}$ & $\begin{array}{c}\text { Female } \\
\mathbf{n}(\%)\end{array}$ & $\begin{array}{c}\text { Total } \\
\mathbf{n}(\%)\end{array}$ \\
\hline 1A & $1(4)$ & $0(0)$ & $1(3)$ \\
1B & $1(4)$ & $0(0)$ & $1(3)$ \\
1C & $5(19)$ & $0(0)$ & $5(14)$ \\
1D & $5(19)$ & $1(13)$ & $6(18)$ \\
2 & $14(54)$ & $7(87)$ & $21(62)$ \\
Total & $26(100)$ & $8(100)$ & $34(100)$ \\
\hline
\end{tabular}


and four $(12.0 \%)$ in the area of General Pediatrics. Three (9.0\%) researchers appointed the areas of Nephrology, Endocrinology, Gastroenterology, Hematology, and Rheumatology. The areas of Neonatology, Surgery, and Immunology had two researchers $(6.0 \%)$ each. Other specialties were represented by one researcher each: Neuroscience, Intensive care, and Genetics.

The median time since receiving the doctorate was of 13.5 years (IQ=9-21). Regarding the institution of study, 33 researchers obtained their $\mathrm{PhD}$ in Brazil, and only one in the United States. Five institutions were responsible for approximately $85 \%$ of researchers: USP ( $n=14 ; 41.0 \%)$, UNIFESP $(n=7 ; 21.0 \%)$, UFMG ( $\mathrm{n}=5 ; 15.0 \%$ ), and Universidade Federal do Rio Grande do Sul (UFRGS) ( $\mathrm{n}=3 ; 9.0 \%)$. Half of the researchers $(\mathrm{n}=17$; $50.0 \%$ ) obtained their post-doctoral studies abroad, predominantly in institutions in the United States.

During their entire academic career, $\mathrm{CNPq}$ researchers in Pediatrics have supervised 290 undergraduate students per researcher (median: 6; IQ=1-13), besides 390 masters' students (median: 9; $\mathrm{IQ}=4-18$ ), and 169 doctoral students (median: 4; $\mathrm{IQ}=1-6)$. The medians of supervisions in relation to adjusted values for time since receiving the doctorate were: 0.66 undergraduate students/year, 0.70 master's students/year, and $0.26 \mathrm{PhD}$ students/year. When compared the values adjusted for time of doctoral completion, there was no significant difference between researcher categories regarding the supervision of undergraduate students (Mann-Whitney; $p=0.07$ ) and master's students (MannWhitney; $p=0.57$ ), but there was difference in relation to $\mathrm{PhD}$ students. The median of supervisions of $\mathrm{PhD}$ students for category
1 researchers was of $0.36 /$ year and, for category 2 researchers, 0.13/year (Mann-Whitney; $p=0.046$ ).

In the entire academic career, researchers published 3,122 articles in journals, with a median of 89 articles by researcher (IQ=51-119), ranging from a minimum of 26 to a maximum of 269 articles. In total, 1,258 articles were indexed in the JCR database, approximately $40 \%$ of the total number of articles published (median by researcher: 33; IQ=24-45). In Scopus, 1,827 articles were indexed (median: 45; IQ=33-72), equivalent to $58.5 \%$ of academic production.

Considering the number of articles adjusted for career time, the median was 5.4 publications/year ( $I Q=4.1-8.1$ ). The mean adjusted for articles published in the WoS database was of 2.4/year (IQ=1.5-3.8) and, in Scopus, 3.4/year (IQ=2.4-4.8). Comparing the values adjusted by doctoral time, there was no significant difference between the categories of researchers according to the number of articles published throughout the career (Mann-Whitney; $p=0.27$ ) and articles indexed in the JCR (Mann-Whitney; $p=0.08$ ). However, there was significant difference of articles indexed in the Scopus database (Mann-Whitney; $p=0.016$ ).

Most researchers ( $\mathrm{n}=32 ; 94 \%)$ increased the scientific production in the last 5 years, considering the average number of articles published per year. This increase ranged from 10 to $304 \%$, with median of $84 \%$ (IQ=53-152\%) increase in the scientific production. The median of articles published in the scientific career of the 34 researchers was of four per year $(\mathrm{IQ}=3.1-5.3)$, while, over the past 5 years, it reached eight $(\mathrm{IQ}=5.9-10.0)$. Graph 1 illustrates

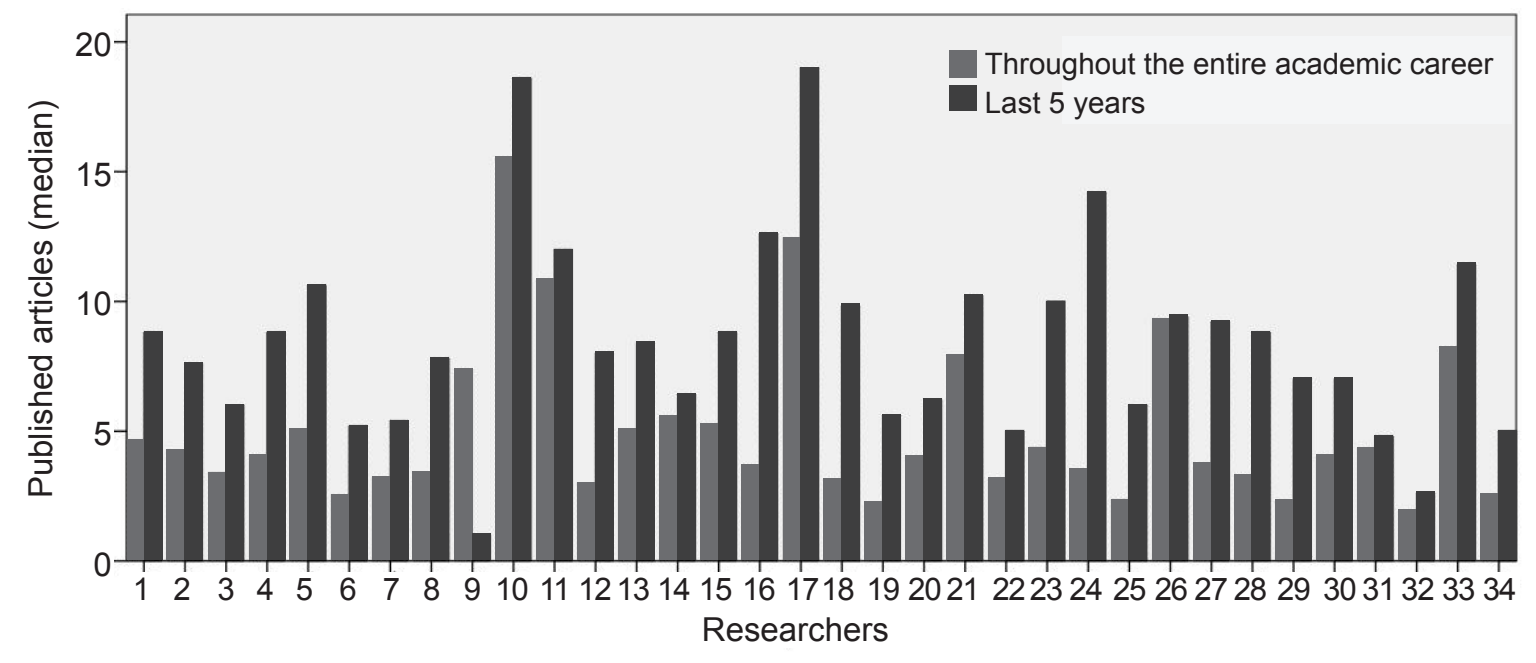

Graph 1 - Median of articles published/year across their scientific career and in the last 5 years by 34 CNPq researchers in the area of Pediatrics 
the mean of articles published in the entire scientific career and the mean over the last 5 years for 34 researchers.

In the entire academic career, researchers in Pediatrics published in 599 journals. Of this total, the Impact Factor (IF) of 323 journals (54\%) was identified in the JCR (Journal Citation Report) database in base year 2009. The median of the IF was of 2.35 ( $\mathrm{IQ}=1.37-3.73$ ), ranging from 0.024 to 47.05 in the extremes. In relation to the distribution of the IF, 38 (11.7\%) journals had IF<one; 95 (29.4\%) journals between one and two; $76(23.5 \%)$ journals between two and three; 42 (13\%) between three and four; $23(7.1 \%)$ between four and five; and $49(15.1 \%)$ had an IF > five. Graph 2 illustrates the distribution of the IF of journals in which the 3,122 articles from the researchers in Pediatrics were published. It is observed that most articles were

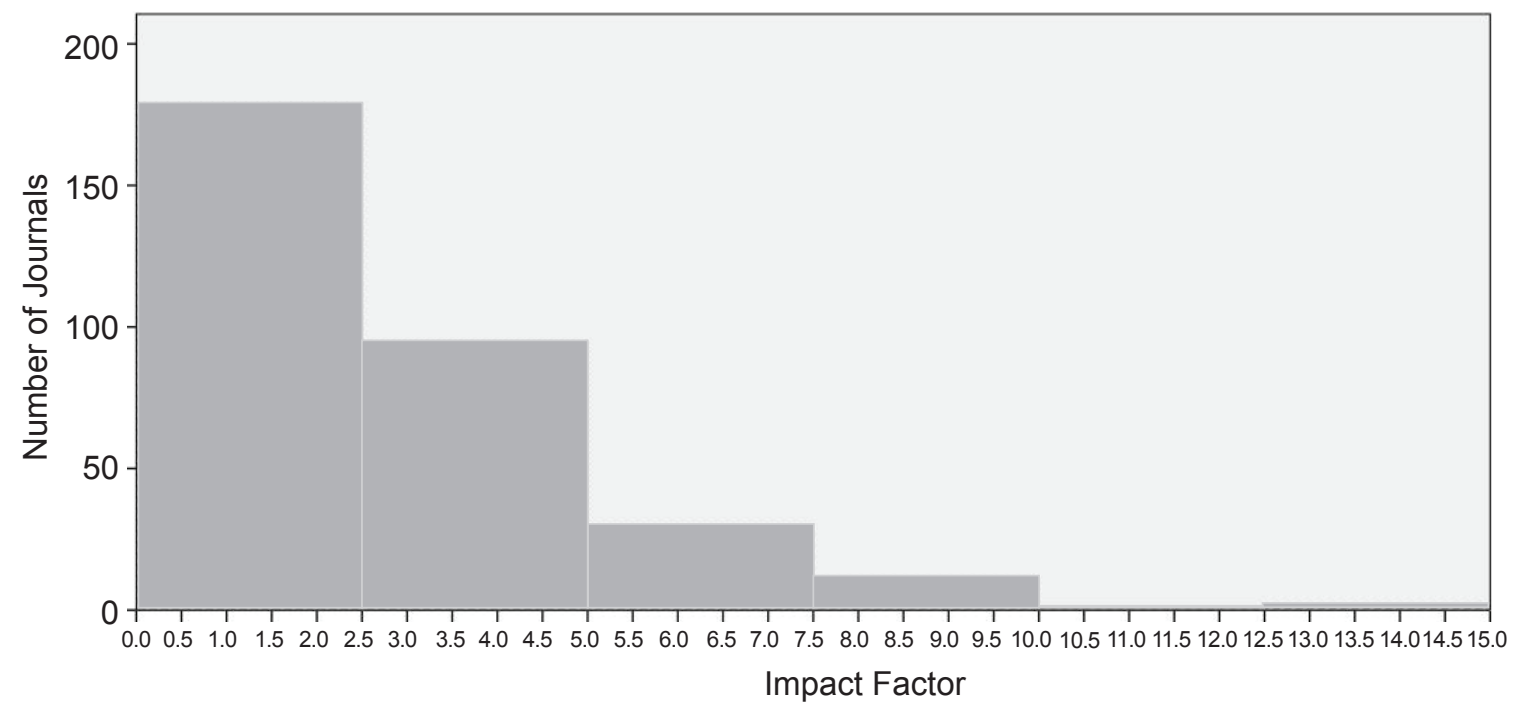

Graph 2 - Distribution of the Impact Factor of the journals in which articles by CNPq researchers in Pediatrics were published. The graph shows the distribution of the Impact Factor to the limit of 15 (11 journals with greater values were excluded in the presentation of the graph)

Table 2 - Distribution of the 15 journals indexed in the JCR database most used for publication by CNPq researchers in the area of Pediatrics

\begin{tabular}{lccccc}
\hline \multirow{2}{*}{ Indexed Journals } & \multicolumn{3}{c}{ Impact Factor } & \multirow{2}{*}{ Articles } & \multirow{2}{*}{$\%$} \\
\cline { 2 - 4 } & $\mathbf{2 0 0 9}$ & $\mathbf{2 0 1 0}$ & $\mathbf{2 0 1 1}$ & 443 & 14.20 \\
Jornal de Pediatria & 1.380 & 1.065 & 1.013 & 85 & 2.72 \\
Braz J Med Biol Res & 1.070 & 1.150 & 1.129 & 66 & 2.11 \\
Arq Bras Endoc Metabol & 0.680 & 1.003 & 0.879 & 46 & 1.47 \\
J Ped Gastroenterol Nut & 2.186 & 2.180 & 2.298 & 42 & 1.34 \\
J Clin Endocrinol Metabol & 6.202 & 6.495 & 5.967 & 39 & 1.25 \\
Rev Assoc Med Bras & 0.580 & 0.553 & 0.771 & 35 & 1.12 \\
Cad Saúde Publica & 0.829 & 0.987 & 0.889 & 32 & 1.02 \\
J Pediatrics & 4.090 & 4.042 & 4.115 & 30 & 0.96 \\
J Trop Ped & 1.220 & 1.248 & 1.388 & 29 & 0.92 \\
Leukemia Res & 2.350 & 2.550 & 2.923 & 29 & 0.92 \\
Pediatric Pulmon & 1.180 & 2.239 & 2.533 & 29 & 0.92 \\
Arq Neuro-psiquiatria & 0.550 & 0.574 & 0.722 & 27 & 0.85 \\
Acta Pediatric & 1.768 & 1.955 & 2.073 & 24 & 0.77 \\
Ped Blood Cancer & 2.130 & 1.948 & 1.891 & 23 & 0.73 \\
Pediatric Research & 2.600 & 2.803 & 2.700 & & \\
\hline
\end{tabular}


published in journals with IF between 1 and 2 . In relation to the scientific journals, Table 2 presents the 15 scientific journals most used by fellows in their publications.

Throughout their academic career, researchers in Pediatrics received a total of 11,290 citations in the WoS database, with a median of 284 quotes by researcher (IQ=120-372, ranging from 25 to 1,678 quotes). The median by article was 7 quotes (IQ=5-10). In Scopus, 14,154 quotes to researchers of Pediatrics were identified, with a median of 329 quotes by researcher (IQ=176-446, ranging from a minimum of 57 to a maximum of 1,940 quotes). The median of citations per article in the Scopus database was six $(I Q=4-9)$.

The median of $h$-index in the JCR database was eight $(\mathrm{IQ}=6-$ 11 ), ranging from a minimum of four to a maximum of 25 . The corresponding value for the median for the $h$-index in Scopus was of $9(\mathrm{IQ}=7-11)$, ranging from a minimum of 5 to a maximum of 24 . There was a significant difference in the median of the $b$-indexes, according to the fellowship category of the researcher in WoS database (Mann-Whitney; $p=0.03$ ), but there was no difference in the Scopus database (Mann-Whitney; $p=0.08$ ).

The median of the $m$-index, i.e., the $h$-index corrected by the time of academic career of the researcher, was of 0.56 in the WoS database (IQ=0,39-0,80), ranging from a minimum of 0.22 to a maximum of 1.30 . The corresponding value of median for the $m$ index in the Scopus database was of $0.56(\mathrm{IQ}=0.38-0.77)$, ranging from a minimum of 0.20 to a maximum of 1.41 . However, no significant difference was found for the $m$-index among fellowship categories in both databases: JCR (Mann-Whitney; $p=0.70$ ) and Scopus (Mann-Whitney; $p=0.67$ ).

\section{Discussion}

The present study showed that there is still a large concentration of training centers for researchers and few institutions with high productivity that deal with research involving the health of children and adolescents. The results confirm the large concentration of scientific production in a few states, especially in São Paulo, as previously demonstrated ${ }^{(21)}$. Blank et a ${ }^{(21)}$ assessed the international insertion of Brazilian scientific production in the field of Pediatrics. These authors demonstrated that there was a large concentration of scientific production in São Paulo, which remained stable throughout the study period (1990-2004). This research showed that only three states are responsible for approximately $90 \%$ of researchers, and more than half are concentrated in São Paulo (53\%).

The present study showed that most researchers (88\%) in Pediatrics acts in subareas of knowledge, highlighting the specialty of Pneumology, with $17.6 \%$ (6/34) of researchers. The study identified only four researchers $(12 \%)$ working in the area of primary care in Pediatrics and who were not linked to subspecialties. The absence of important areas like Pediatric Cardiology was also noteworthy, despite the fact that Cardiology, as a specialty, represents approximately $8 \%$ of $\mathrm{CNPq}$ researches in Medicine ${ }^{(14,22)}$.

A point to be emphasized in this analysis is the significant increase in scientific production in the last 5 years, a fact that was also observed in other areas such as Dentistry, Public Health and Physiotherapy ${ }^{(9-11,13)}$. On average, CNPq researchers in the area of Pediatrics doubled the number of articles published in the last 5 years.

The analysis of researchers in Pediatrics showed a significant number of articles published in medium IF journals. During the academic career, the median was of 89 articles by researcher, similar to the mean of 87 articles from the 411 research fellows in the area of Medicine, observed in a previous study ${ }^{(14)}$. It should be noted that approximately $40 \%$ of all published articles were indexed in the JCR database and $58.5 \%$, in the Scopus database, which are important parameters of quality in scientific production. However, it is interesting to note that these qualitative data are lower compared to the general analysis of the 411 researchers in the field of Medicine. In this previous analysis, it was observed that approximately 51 and $68 \%$ of all published articles were indexed in the WoS and Scopus databases, respectively ${ }^{(14)}$. These data are also lower than data of researchers in the subareas of Cardiology and Nephrology, for instance, which had 55 and $58 \%$ of articles indexed in the JCR database, respectively ${ }^{(22,23)}$. This scenario may certainly change in the coming years with the recent indexing of Jornal de Pediatria (Brazilian Journal of Pediatrics) in the JCR database and with the obtaining of an IF greater than 1,00 in the first assessment in 2009 ${ }^{(24)}$. In this context, another positive point was the indexing, in 2011, of Revista Paulista de Pediatria (Journal of Pediatrics of the state of São Paulo) in Scopus database.

It should be noted that, among the 599 journals used by researchers in Pediatrics, 323 (54\%) are indexed in the JCR database, with a median IF of 2.35 . It is also noted that approximately $15 \%$ of these journals exhibit an IF greater than five. The same database shows that, among the 94 journals indexed in the area of Pediatrics, only four $(10.5 \%)$ have an IF greater than 4 , and none presents an IF greater than five. According to data from 2009 from the JCR, the median IF of the 94 journals in Pediatrics was of 1.4. These data reinforce the quality of the scientific production of this group of researchers. 
Despite substantial criticism of the use of the IF of journals in the evaluation of institutions and researchers, this index continues to be adopted by many agencies that support research ${ }^{(17,19,25-30)}$. In this context, stands out the importance of valuing Brazilian journals, an essential factor for national scientific development, as emphasized in a recent editorial signed by important editors of national publications ${ }^{(31,32)}$. It is of particular interest that, although this study was not designed to answer this question, such findings regarding the IF of journals in which the most productive researchers in Pediatrics publish, reinforce the criticisms about the new Capes'Qualis ${ }^{(33)}$. As mentioned, our study showed a median IF of 2.35 and a 75 th percentile of 3.73 . According to documents of Capes regarding the area Medicine II, which include Post-Graduation programs in Pediatrics, journals are classified as $\mathrm{A} 1$, when the IF $\geq 4$, and as A2, when the IF is situated between

\section{References}

1. Goldani MZ, Gurgel RQ, Blank D, Gerolin J, Mari JJ. Pursuing efficiency: international visibility of the scientific production of Brazilian graduate programs in child and adolescent health from 1998 through 2003. J Pediatr (Rio J) 2007;83:436-40.

2. King DA. The scientific impact of nations. Nature 2004;430:311-6.

3. Pinheiro-Machado R, de Oliveira PL. The Brazilian investment in science and technology. Braz J Med Biol Res 2001;34:1521-30.

4. Zorzetto R, Razzouk D, Dubugras MT, Gerolin J, Schor N, Guimarães JA et al. The scientific production in health and biological sciences of the top 20 Brazilian universities. Braz J Med Biol Res 2006;39:1513-20.

5. Petherick A. High hopes for Brazilian science. Nature 2010;465:674-5.

6. Regalado A. Science in Brazil. Talented but underfunded: Brazil's future scientists. Science 2010;330:1311.

7. Deheinzelin D, Caramelli B. Scientific production, post-graduate education and Revista da Associação Médica Brasileira. Rev Assoc Med Bras 2007;53:471-2.

8. Guimarães R. Challenges of postgraduate human health programs in Brazil. Rev Saude Publica 2011;45:1-13.

9. Santos NC, Candido LF, Kuppens CL. Research productivity of CNPq: analysis of the chemistry researchs' profile. Quim Nova 2010;33:489-95.

10. Barata RB, Goldbaum M. A profile of researchers in public health with productivity grants from the Brazilian National Research Council (CNPq). Cad Saude Publica 2003;19:1863-76.

11. Cavalcante RA, Barbosa DR, Bonan PR, Pires MB, Martelli-Júnior H. Profile of dentistry researchers of the Brazilian National Research Council (CNPq). Rev Bras Epidemiol 2008;11:106-13.

12. Mendes PH, Martelli DR, Souza WP, Quirino Filho S, Martelli Júnior H. Profile of medical researchers with scietinfic productivity grants from the Brazilian National Research Council (CNPq). Rev Bras Educ Med 2010;34:535-41.

13. Santos SM, Lima LS, Martelli DR, Martelli-Júnior H. Abstract of public health researchers in the National for Scientific and Technological Developmental. Physis 2009;19:761-75.

14. Martelli-Junior H, Martelli DR, Quirino IG, Oliveira MC, Lima LS, Oliveira EA. CNPq researchers in medicine: a comparative study of research areas. Rev Assoc Med Bras 2010;56:478-83.

15. Oliveira EA, Colosimo EA, Martelli DR, Quirino IG, Oliveira MC, Lima LS et al. Comparison of Brazilian researchers in clinical medicine: are criteria for ranking well-adjusted? Scientometrics 2011;90:429-43.

16. Bornmann L, Mutz R, Daniel HD. Are there better indices for evaluation purposes than the $h$ index? A comparison of nine different variants of the $h$ index using data from biomedicine. JASIST 2008;59:830-7.
2.8 and $3.999^{(34)}$. Thus, a classification that underestimates an important share of the production of the main researchers in the area of Pediatrics does not seem reasonable.

It may be concluded that researchers in the field of Pediatrics present a relevant scientific output from the quantitative point of view, but that still needs further qualitative improvement.

\section{Acknowledgements}

This study was partially funded by a grant from the Foundation for Research Support of the State of Minas Gerais (Fapemig). Eduardo Araujo Oliveira and Ana Cristina S. e Silva are CNPq researchers category 2 in the field of Medicine. Hercílio MartelliJúnior and Enrico Antonio Colosimo are CNPq researchers category 2 in the areas of Odontology and Statistics, respectively.

17. Haeffner-Cavaillon N, Graillot-Gak C. The use of bibliometric indicators to help peer-review assessment. Arch Immunol Ther Exp (Warsz) 2009;57:33-8.

18. Hirsch JE. An index to quantify an individual's scientific research output. Proc Natl Acad Sci U S A 2005;102:16569-72.

19. Lehmann $S$, Jackson AD, Lautrup BE. Measures for measures. Nature 2006;444:1003-4.

20. Panaretos J, Malesios CC. Assessing scientific research performance and impact with single indices. Scientometrics 2009;81:635-70.

21. Blank D, Rosa LO, Gurgel RQ, Goldani MZ. Brazilian knowledge production in the field of child and adolescent health. J Pediatr (Rio J) 2006;82:97-102.

22. Oliveira EA, Ribeiro AL, Quirino IG, Oliveira MC, Martelli DR, Lima LS et al. Profile and scientific production of CNPq researchers in cardiology. Arq Bras Cardiol 2011;97:186-93.

23. Oliveira EA, Pécoits-Filho R, Quirino IG, Oliveira MC, Martelli DR, Lima LS et al. Profile and scientific production of CNPq researchers in nephorology and urology. J Bras Nefrol 2011;33:31-7.

24. Procianoy RS. 2009 impact factor: a new reality for Jornal de Pediatria. $J$ Pediatr (Rio J) 2010;84:255-6.

25. Bordons M, Fernández MT, Gómes I. Advantages and limitations in the use of impact factor measures for the assessment of research performance in a peripheral country. Scientometrics 2002;53:195-206.

26. Brink AJ. Impact factor: use and abuse. Cardiovasc J S Afr 2004;15:5-7.

27. Moed HF. New developments in the use of citation analysis in research evaluation. Arch Immunol Ther Exp (Warsz) 2009;57:13-8.

28. Simons K. The misused impact factor. Science 2008;322:165.

29. Szklo M. Impact factor: good reasons for concern. Epidemiology 2008;19:369.

30. Wilcox AJ. Rise and fall of the Thomson impact factor. Epidemiology 2008;19:373-4.

31. Andriolo A, Souza AF, Farias AQ, Barbosa AJ, França Netto AS, Hernandez AJ et al. Classification of Journals in the QUALIS System of CAPES: urgent need of changing the criteria! Arq Bras Cardiol 2010;94:271-2.

32. Andriolo A, Souza AF, Farias AQ, Barbosa AJ, Netto AS, Hernandez AJ et al. Classification of Journals in the Qualis System of Capes: urgent need of changing the criteria! J Bras Nefrol 2010;32:4-6.

33. Rocha-e-Silva M. O novo Qualis, que não tem nada a ver com a ciência do Brasil. Carta aberta ao presidente da Capes. Clinics 2009;64:721-4.

34. Brasil - Ministério da Educação - CAPES [homepage on the Internet]. Brasília: Comunicado ${ }^{\circ}$ 001/2012 - área de Medicina II: atualização do webqualis da área [cited 2012 Nov 23]. Available from: http://www.capes.gov.br/images/ Qualis_-_Medicina_II.pdf 